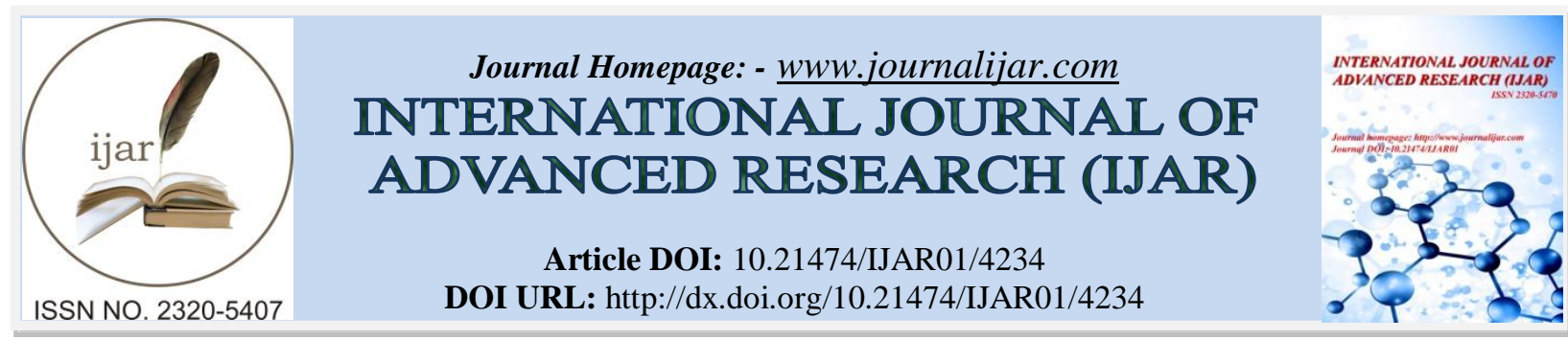

RESEARCH ARTICLE

\title{
ISOLATION AND IDENTIFICATION OF CHLORPYRIFOS DEGRADING BACTERIA FROM AGRICULTURAL SOIL.
}

\section{${ }^{*}$ V. Hamsavathani ${ }^{1}$, Dr. O. S. Aysha ${ }^{2}$ and A. Raughul Ajith ${ }^{3}$.}

1. Assistant Professor, Department of Microbiology, Jaya College of Arts and Science, Thiruninravur and Research Scholar, PG and Research Department of Microbiology, Mohamed Sathak College of Arts and Science, Sholinganallur, Chennai, Tamilnadu, India.

2. Head and Research Coordinator, PG and Research Department of Microbiology, Mohamed Sathak College of Arts and Science, Sholinganallur, Chennai, Tamilnadu, India.

3. Post Graduate Scholar, PG and Research Department of Microbiology, Mohamed Sathak College of Arts and Science, Sholinganallur, Chennai, Tamilnadu, India.

\section{Manuscript Info}

-.........................

Manuscript History

Received: 20 March 2017

Final Accepted: 23 April 2017

Published: May 2017

Key words:-

chlorpyrifos, pesticide, biodegradation, Kocuria

kristinae, Staphylococcus aureus

\section{Abstract}

The extensive use of pesticides in agricultural fields for pest control pose a serious problem in contaminating soil and water ecosystems. Chlorpyrifos is the major broad spectrum organophosphorus insecticide used in paddy fields against sucking, chewing, boring insects. Due to its toxicity and persistence in the environment, there is an immediate need to eliminate them from contaminated sites by biodegradation. Two pesticide degrading bacteria were screened and isolated from chlorpyrifos contaminated soil by enrichment culture technique and were identified as Kocuria kristinae and Staphylococcus aureus. The growth response and degradation of chlorpyrifos by the isolates in MSM broth supplemented with $0.5 \%$ chlorpyrifos was monitored every 48-72 hrs in spectrophotometer at $600 \mathrm{~nm}$. Kocuria sp showed maximum growth in 7 days than Staphylococcus aureus. The degradation efficiency of the strains were determined and estimated by the removal percentage of chlorpyrifos from the liquid culture. Both the isolate showed the degrading capability of chlorpyrifos in MSM. The isolate, $S$. aureus was more potent in degrading the $80 \%$ of the total compound from the media in 2 weeks of incubation than K. kristinae which shows $35 \%$ of degradation. These results were further confirmed by GCMS, in which $S$. aureus has degraded $82.06 \%$ and $K$. kristinae has degraded $\mathbf{3 0 . 7 8 \%}$ of chlorpyrifos in the medium. This study indicates that the isolate, Staphylococcus aureus is more potent in degrading chlorpyrifos in liquid culture and can also be used in bioremediation of chlorpyrifos contaminated soils.

Copy Right, IJAR, 2017,. All rights reserved.

\section{Introduction:-}

Pesticides are BIOCIDES, designed to kill, reduce or repel insects, weeds, rodents, fungi or other organisms that can threaten public health and the economy. Pesticides are designed to kill specific pests and the most widely used are insecticides, rodenticides, herbicides, insect repellents and fungicides. Organophosphorus compounds are the most 
widely used insecticides, accounting for an estimated $34 \%$ of worldwide insecticide sales (1).

Chlorpyrifos (O, O-diethyl O-3, 5, 6-trichloro-2-pyridyl phosphorothioate) are the esters derived from phosphoric acid is one of the broad spectrum organophosphate pesticide used against sucking, chewing and boring insects (Fig 1). It is used for crop protection and also has acaricidal and termiticidal properties. In man, it acts on the central nervous system by inhibiting acetylcholinesterase, an enzyme that modulates the amount and levels of the neurotransmitter acetylcholine and thus disrupting the nerve impulse. Chlorpyrifos causes hazardous effects to the environment and also toxic to human beings resulting in headache, nausea, muscle twitching, convulsions, birth defects and even death (2).

Due to these effects, the need to remove these residues from the environmental sources should be focused. Degradation of chlorpyrifos by microorganisms has become extensively studied as other methods are impractical or costly or environmentally hazardous (3).

To date, several chlorpyrifos-degrading bacterial strains were isolated including Enterobacter sp $(4,5,6)$, Pseudomonas putida (7,8), Ps. aeruginosa (9,10), Ps. desmolyticum (11), Ps. resinovorans (12), Ps. fluorescens (13), Bacillus subtilis $(13,14,15,16)$, Bacillus sp and Micrococcus sp (17,18), B. firmis (19), B. cereus (20), Stenotrophomonas (21), Serratia marcescens, Klebsiella oxytoca (22), Achromobacter sp, Ochrobactrum sp (23), Alcaligenes faecalis (24), Mesorhizobium (25), cellulomonas fimi (26), Gordonia (27), B. polymyxa (28), Kocuria sp (29), Staphylococcus sp, Streptococcus sp, azomonas sp, Flavobacterium sp (30) were extensively studied in degradation of chlorpyrifos.

The objective of this study focuses on isolation and identification of chlorpyrifos utilizing bacteria from agricultural soil especially from paddy field by enrichment culture technique and its ability to degrade chlorpyrifos in liquid culture medium. This study aims at the biotechnological approach in cleaning chlorpyrifos contaminated environment by microbial degradation.

\section{Materials and Methods:-}

\section{Pesticide and Chemicals:-}

Commercial grade of chlorpyrifos (dursban, EC 20\%), a type of organophosphorus pesticide was obtained used for this study. It was purchased from a local agrochemicals shop in Thiruvallur district, Tamil Nadu. The analytical grade chemicals were purchased from HIMEDIA, Chennai.

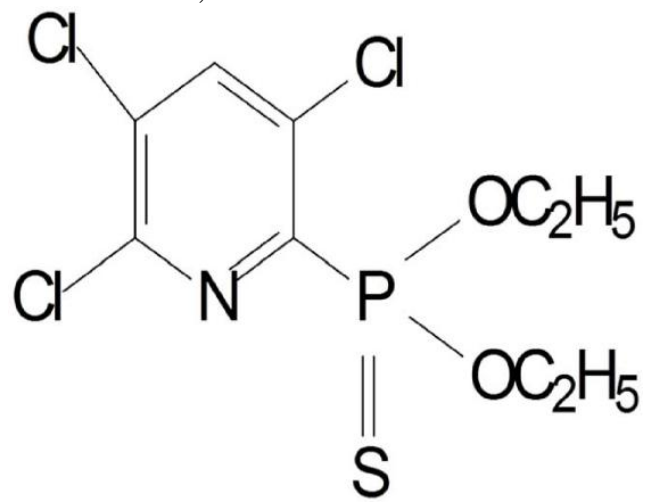

\section{Collection of Soil Samples:-}

Figure 1:- Structure of chlorpyrifos.

The soil samples were collected from ten different paddy fields from places in and around Thiruvallur district. The soil samples were collected from topsoil layer $(0-15 \mathrm{~cm})$ and air dried at room temperature and mixed thoroughly and were stored in sterile bottles in refrigerator at $4{ }^{\circ} \mathrm{C}$.

\section{Enrichment Culture Technique:-}

The Enrichment culture technique was used for the isolation of bacterial strains capable of utilizing chlorpyrifos as a sole source of carbon and energy. Soil enrichment was carried out in minimal salt medium (MSM, pH 7.0) containing (g/L) Dextrose, 1.0; $\mathrm{K}_{2} \mathrm{HPO}_{4}, 7.0 ; \mathrm{KH}_{2} \mathrm{PO}_{4}, 2.0$; Sodium citrate, 0.5; $\mathrm{MgSO}_{4} .7 \mathrm{H}_{2} \mathrm{O}, 0.1 ; \mathrm{NH}_{3}\left(\mathrm{SO}_{4}\right)_{2}, 1.0$; Agar, 15.0 with pH $7.0 \pm 0.2$ (4). 


\section{Isolation and Screening of Chlorpyrifos Degrading Bacteria:-}

One gram of each soil sample was dispersed in $100 \mathrm{ml}$ of sterile distilled water and were serially diluted. The last three dilutions $10^{-5}, 10^{-6}$ and $10^{-7}$ were inoculated in MSM broth, supplemented with $0.5 \mathrm{ml} / \mathrm{L}$ of chlorpyrifos and incubated at $28^{\circ} \mathrm{C}$ for 7 days.

From the enrichment culture, one $\mathrm{ml}$ of aliquots were transferred to the fresh MSM broth and it was incubated at $28^{\circ} \mathrm{C}$ for 7 days. This procedure was repeated thrice for selective enrichment and isolation of chlorpyrifos degrading bacteria.

Finally, $1 \mathrm{ml}$ from the above medium were inoculated on MSM agar plates and incubated at $28^{\circ}$ for 5 days. Single colony from MSM agar plates were picked up aseptically and were sub-cultured on MSM agar slants and stored at $4^{\circ} \mathrm{C}$ for further use.

\section{Identification of Bacteria:-}

Microscopic and Biochemical tests were performed for determining the phenotypic characterization of the chlorpyrifos degrading isolates. They were examined for the colony morphology, pigmentation, and routine preliminary tests such as Gram's reaction, motility and biochemical tests like IMViC test, Oxidase test, Catalase Test, urease test, Carbohydrate fermentation test, $\mathrm{NO}_{2}$ reduction test, casein and starch hydrolysis, $\mathrm{H}_{2} \mathrm{~S}$ production and confirmed by Bergey's manual of determinative Bacteriology $(31,32)$.

The identification of bacteria was done by using The BD Phoenix ${ }^{\mathrm{TM}}$ Automated Microbiology System for the in vitro rapid identification (ID) and quantitative determination of antimicrobial susceptibility by minimal inhibitory concentration (MIC)

\section{Degradation of Chlorpyrifos:-}

The bacterial isolates were examined for their potential to degrade chlorpyrifos in liquid medium. $0.5 \%$ of chlorpyrifos was added to $100 \mathrm{ml}$ of MSM medium and the isolates were inoculated with a uniform cell density of $0.8 \mathrm{OD}$. It was incubated at $30^{\circ} \mathrm{C}$ for 14 days in a rotary shaker at $150 \mathrm{rpm}$. Un-inoculated flasks were also prepared to check for the abiotic degradation under similar conditions. The experiment was conducted with three replicates.

Growth response of the isolates and degradation were observed at every 48-72 hrs interval in spectrophotometer at $600 \mathrm{~nm}$ (23). The content of the flasks were checked by taking $5 \mathrm{ml}$ of culture drawn from mineral based medium and centrifuged at $5000 \mathrm{rpm}$ for 10 minutes. The pellet was discarded and the supernatant was analyzed by spectrophotometer.

Percent degradation of compound was determined by using the formula

Percent degradation $=\mathrm{Ab}-\mathrm{Aa} \div \mathrm{Ab}{ }^{\times} 100$

Where,

$\mathrm{Ab}$ is absorbance of compound before degradation.

Aa is absorbance of compound after degradation (11).

\section{Extraction of Chlorpyrifos from Samples:-}

The media was centrifuged at $5000 \mathrm{rpm}$ for 15 minutes. The supernatant was extracted and it was used for GC-MS analysis.

$10 \mathrm{ml}$ of sample which was obtained in the previous step was taken in centrifuge tube with $2 \mathrm{ml}$ of ethyl acetate and thoroughly mixed in vortex mixture for 10 minutes. Then it was centrifuged at $5000 \mathrm{rpm}$ for 5 minutes and the ethyl acetate layer was separated and injected in GC-MS. Control was set up with the same additions except the degraded sample.

Gas Chromatography Mass Spectrometry (GC-MS) Analysis:-

Gas chromatography mass spectrometry (GC-MS) analysis were performed with an Agilent triple Q GCMSMS 7890A gas chromatograph, equipped with a HB $5 \mathrm{MS}(30 \mathrm{~m} \times 0.25 \mathrm{~mm} \times 0.25 \mu \mathrm{m}$ film thickness), an auto-injector and an Agilent network mass selective detector. Nitrogen was used as the carrier gas with a constant flow rate of 0.8 $\mathrm{ml} / \mathrm{min}$. The injector and transfer lines were $280^{\circ} \mathrm{C}$ and $300^{\circ} \mathrm{C}$, respectively. The chromatography program was as follows: total runtime $11 \mathrm{~min}$, initial temperature of column $60^{\circ} \mathrm{C}$, a temperature increase of $25^{\circ} \mathrm{C} / \mathrm{min}$ and final heating to $310^{\circ} \mathrm{C}$. The retention time of chlorpyrifos were detected and percent of degradation were determined by qualitative analysis report. 


\section{Results and Discussion:-}

Ten samples were processed by the enrichment culture technique for the isolation of bacterial strains. Soil enrichment was carried out in minimal salt medium with the chlorpyrifos $(0.5 \%)$, which are capable of utilizing it as a sole source of carbon and energy. The soil samples S7, S6, S10 and S9 showed maximum absorbance of 0.49, $0.40,0.35$ and 0.33 respectively, in enrichment culture technique after 7 days of incubation (Table 1). Among all the isolates, the organisms with maximum OD values (S7 and S6) were processed for identification. Both the organisms were identified by cultural and biochemical tests and confirmed by BD Phoenix Automated Microbiology system. Isolate S6 was identified as Kocuria kristinae and S7 as Staphylococcus aureus (Tables 2 and 3 and Figs 2 and 3) $(17,18)$.

The growth response of the isolates in MSM supplemented with chlorpyrifos $(0.5 \%)$ showed that both the isolates utilized the insecticide as the only carbon source (34). Similar results are obtained by Nagavardhanan et al. (33), who studied on the growth of Kocuria sp. in chlorpyrifos incorporated MSM as the only carbon source. The OD values were observed at $600 \mathrm{~nm}$ at every $48-72$ hours indicating that $K$. kristinae showed maximum growth in 7 days of incubation when compared with.S. aureus (Table 4 and Figs 4, 5, and 6).

The degradation efficiency of the strains were determined and estimated by the removal percentage of Chlorpyrifos from the liquid culture. Both the isolate showed the degrading capability of Chlorpyrifos in MSM. The isolate, $S$. aureus was more potent in degrading the $80 \%$ of the total compound from the media in 2 weeks of incubation followed by K. kristinae which shows $35 \%$ of degradation. These results were confirmed by GCMS (35). From the qualitative analysis report, the RT value of chlorpyrifos was found to be $9.63 \mathrm{~min}$, which was accordance with the study conducted by Rokade et al. (11), who recorded the retention time of chlorpyrifos as $9.55 \mathrm{~min}$ in GC MS.

The residual concentration of chlorpyrifos in sample 2 (Staphylococcus aureus) and sample 1 (Kocuria kristinae) were estimated as $17.94 \%$ and $69.22 \%$ respectively. From the results, it was concluded that the $S$. aureus has degraded 82.06\% (100 - 17.94) and K. kristinae has degraded 30.78\% (100 - 69.22) of chlorpyrifos in MSM (Figs. 7 to 11 , Tables 5 to 7$)$.

The difference is the degradation percentage at the same concentration $(0.5 \% \mathrm{v} / \mathrm{v})$ of chlorpyrifos is due to the ability of the microbe to utilize available chlorpyrifos. The substrate availability is a key factor determining the rate of degradation of the pesticide by the bacterial agents. According to Sharma et al. (17), the chlorpyrifos degrading organisms Bacillus $s p$ and Micrococcus $s p$ showed $71.6 \%$ at $0.1 \% \mathrm{v} / \mathrm{v}$ and $46 \%$ at $0.05 \% \mathrm{v} / \mathrm{v}$ of chlorpyrifos after 10 days of incubation where as in the case of Bacillus sp $40 \%$ and $44 \%$ at the same concentrations.

\section{Conclusion:-}

The present study focusses on isolation of two bacteria Kocuria kristinae and Staphylococcus aureus from chlorpyrifos contaminated soil and their degrading ability in medium containing pesticide. Both the isolates were able to utilize and grow in the presence of chlorpyrifos indicates that they may be used for bioremediation of pesticide contaminated soil.

Table 1: Absorbance of samples at $600 \mathrm{~nm}$

\begin{tabular}{|l|l|l|}
\hline Absorbance at $600 \mathbf{~ n m}$ & Samples & S. No \\
\hline 0.03 & S1 & 1 \\
\hline 0.15 & S2 & 2 \\
\hline 0.03 & S3 & 3 \\
\hline 0.29 & S4 & 4 \\
\hline 0.06 & S5 & 5 \\
\hline 0.40 & S6 & 6 \\
\hline 0.49 & S7 & 7 \\
\hline 0.21 & S8 & 8 \\
\hline 0.33 & S9 & 9 \\
\hline 0.35 & S10 & 10 \\
\hline 0.00 & Control & 11 \\
\hline
\end{tabular}


Figure 2:- Isolated colonies of Kocuria kristinae (Sample 6). Pale yellow with round, translucent, mucoid colonies with measure $2-5 \mathrm{~mm}$ in diameter.

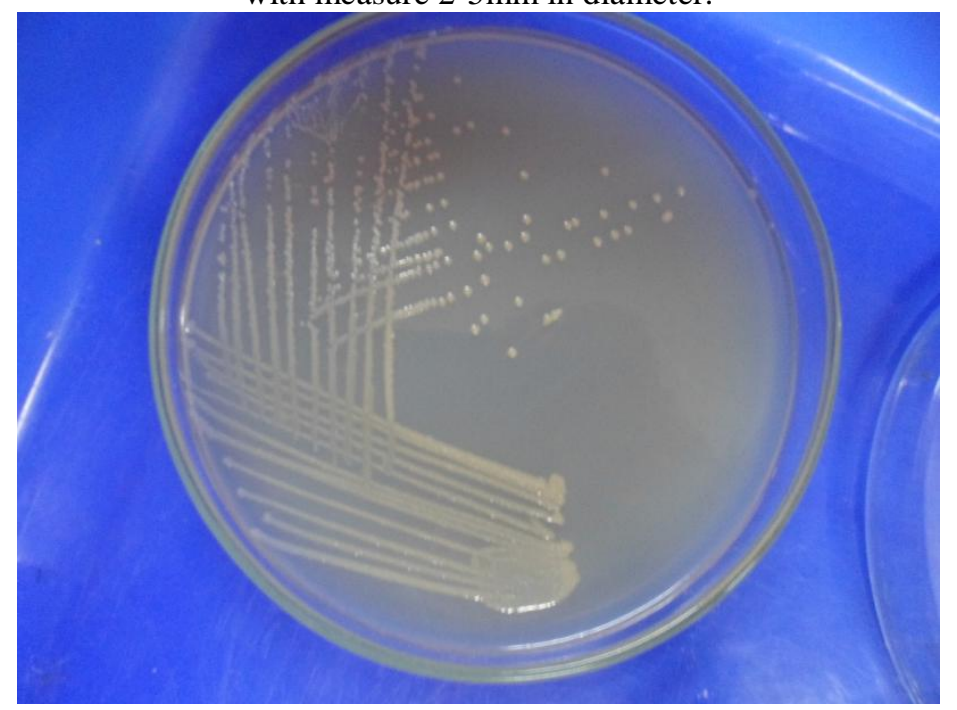

Figure 3:- Isolated Colonies of Staphylococcus aureus (Sample 7). Round, mucoid, with yellow pigment with measures $2-4 \mathrm{~mm}$ in diameter

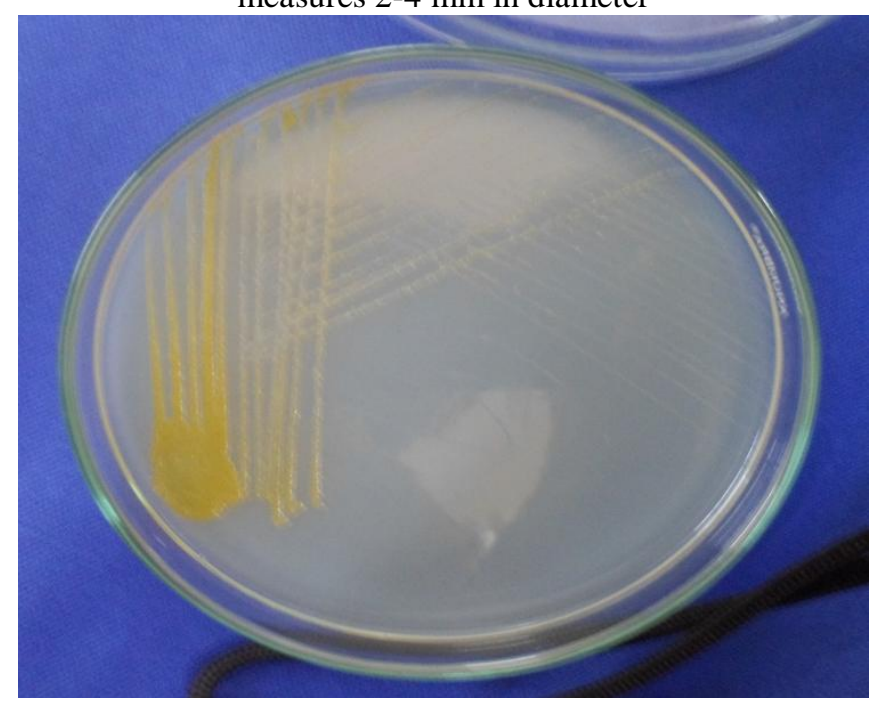


Table -2:- Identification test results for kocuria kristinae

Printed Dec 11, 2016 15:00 IST Printed by:

Patient Name:

Isolate Group: WHITE-8

Patient ID:

Bionümber: 01003030201121

Selected Organism: Kocuria kristinae

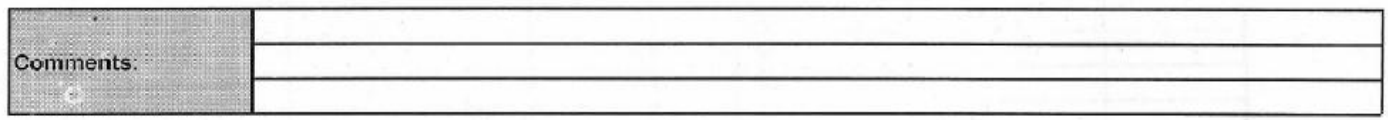

\begin{tabular}{|c|c|c|c|c|c|}
\hline \multirow{2}{*}{$\begin{array}{l}\text { Identification } \\
\text { Information }\end{array}$} & Card: $\quad$ GP & $\begin{array}{l}\text { Lot } \\
\text { Number: }\end{array}$ & 2420022103 & Expires: & $\begin{array}{l}\text { Dec 18, } 2017 \text { 12:00 } \\
\text { IST }\end{array}$ \\
\hline & \begin{tabular}{|l|l} 
Completed: & $\begin{array}{l}\text { Dec 9, } 2016 \\
20: 45 \text { IST }\end{array}$ \\
\end{tabular} & Status: & Final & $\begin{array}{l}\text { Analysis } \\
\text { Time: }\end{array}$ & 5.00 hours \\
\hline jelected Organism & $\begin{array}{l}93 \% \text { Probability } \\
\text { Bionumber: } 010030302011211\end{array}$ & \multicolumn{2}{|c|}{ Kocuria kristinae } & Confidence: & $\begin{array}{l}\text { Very good } \\
\text { identification }\end{array}$ \\
\hline $\begin{array}{l}\text { SRF } \\
\text { Organism }\end{array}$ & & & & & \\
\hline Analusis Organisms and & s to Separate: & & & & \\
\hline Analysie Messages: & & & & & \\
\hline $\begin{array}{l}\text { Contraindicating Typlcal } \\
\text { Kocuria kristinae }\end{array}$ & $\begin{array}{l}\text { jattern(s) } \\
\text { NOVO(1),O129R(7), }\end{array}$ & & & & \\
\hline
\end{tabular}

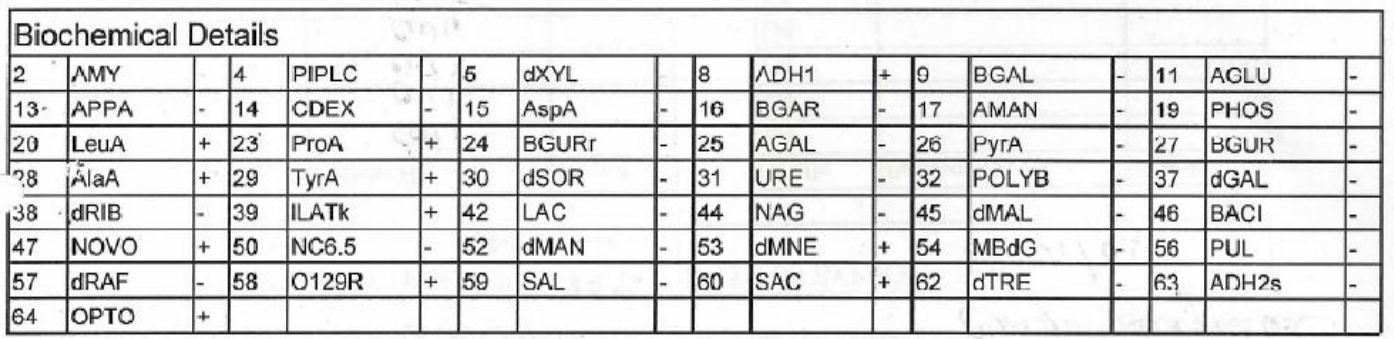


Table 3:- Identification test results for Staphylococcus aureus

\section{Comments:}

\begin{tabular}{|c|c|c|c|}
\hline Identification Information & Analysis Time: & 5.00 hours & Final \\
\hline \multirow[b]{2}{*}{ Selected Organism } & $95 \%$ Prubability & Staphylocaccus aureus & \\
\hline & Bionumber: & 070402076763271 & \\
\hline \multicolumn{4}{|l|}{ Organiem Quantity: } \\
\hline ID Analysis Messages & & & \\
\hline
\end{tabular}

\section{Biochemical Details}

\begin{tabular}{|l|l|l|l|l|l|l|l|l|l|l|l|l|l|l|l|l|l|}
\hline 2 & AMY & - & 4 & PIPI C & - & 5 & dXYL & - & 8 & ADH1 & + & 9 & BGAL & + & 11 & AGLU & + \\
\hline 13 & APPA & - & 14 & CDEX & - & 16 & Asp $\wedge$ & & 16 & BGAR & & 17 & AMAN & & 19 & PHOS & + \\
\hline 20 & LeuA & - & 23 & PrOA & - & 24 & BGURI & - & 25 & AGAL & - & 26 & PyIA & + & 27 & BGUR & - \\
\hline 28 & AllaA & - & 29 & TyrA & - & 30 & dSOR & - & 31 & URE & + & 32 & POLYB & + & 37 & dGAL & + \\
\hline 38 & dRIB & - & 39 & LATk & + & 42 & LAC & + & 44 & NAG & + & 45 & dMAL & + & 46 & BACl & + \\
\hline 47 & NOVO & - & 50 & NC6.5 & + & 52 & dMAN & + & 53 & dMNE & + & 54 & MBdG & + & 56 & PUL & - \\
\hline 57 & dRAF & - & 58 & $0129 R$ & + & 59 & SAL & - & 60 & SAC & + & 62 & dTRE & + & 63 & ADH2S & + \\
\hline 64 & OPTO & + & & & & & & & & & & & & & & & \\
\hline
\end{tabular}

Table 4:- Growth response of the isolates in MSM with chlorpyrifos

\begin{tabular}{|l|l|l|l|}
\hline Absorbance of 600 nm & Kocuria kristinae & Control & Days \\
\hline Staphylococcus aureus & 1 & 1 & 1 \\
\hline 1 & 1.12 & 1 & 4 \\
\hline 1.02 & 1.44 & 1 & 7 \\
\hline 1.25 & 1.09 & 1 & 10 \\
\hline 0.86 & 0.65 & 1 & 14 \\
\hline 0.20 & & 1 & 1 \\
\hline
\end{tabular}


Figure 4:- Growth response of $K$. kristinae $(\mathrm{X}$ axis $=$ days: $\mathrm{Y}$ axis $=$ absorbance at $600 \mathrm{~nm})$.

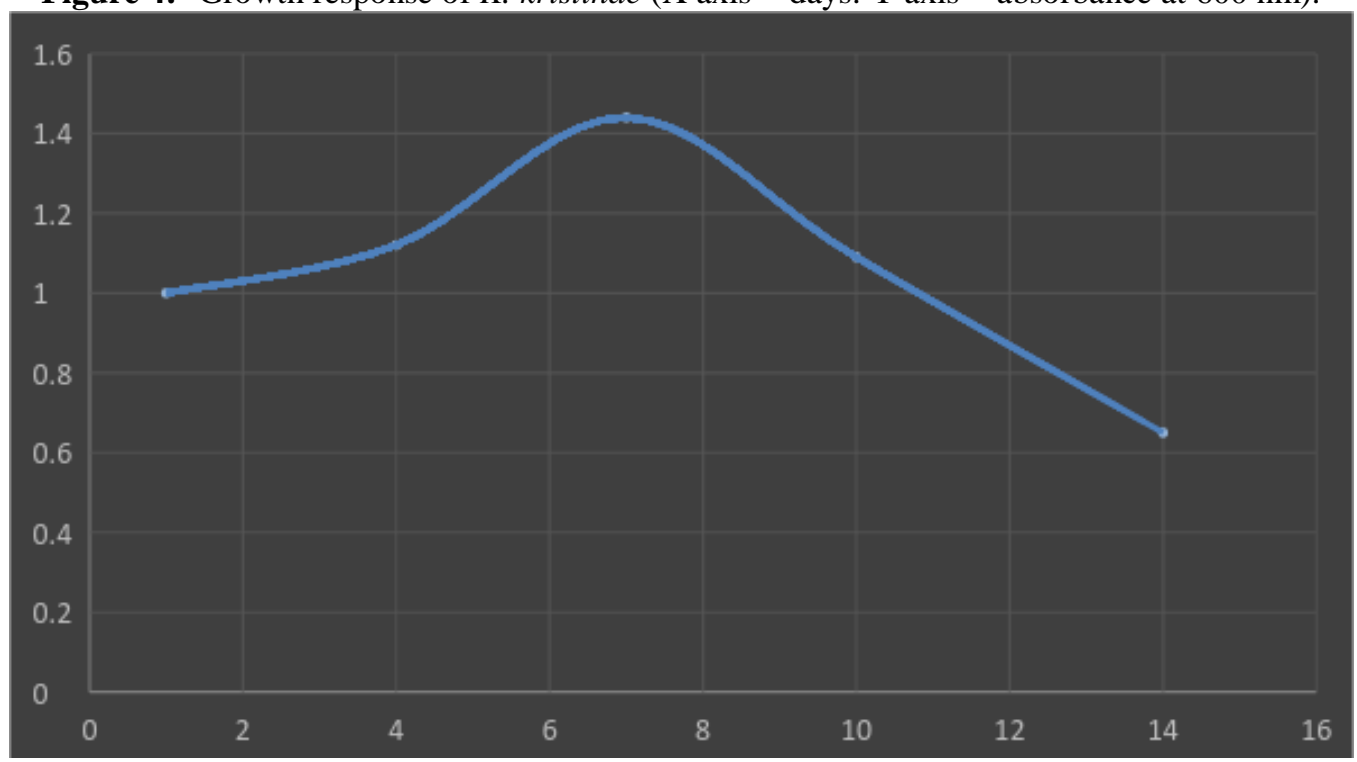

Figure 5:- Growth response of $S$. aureus $(\mathrm{X}$ axis $=$ days: $\mathrm{Y}$ axis $=$ absorbance at $600 \mathrm{~nm}$ ).

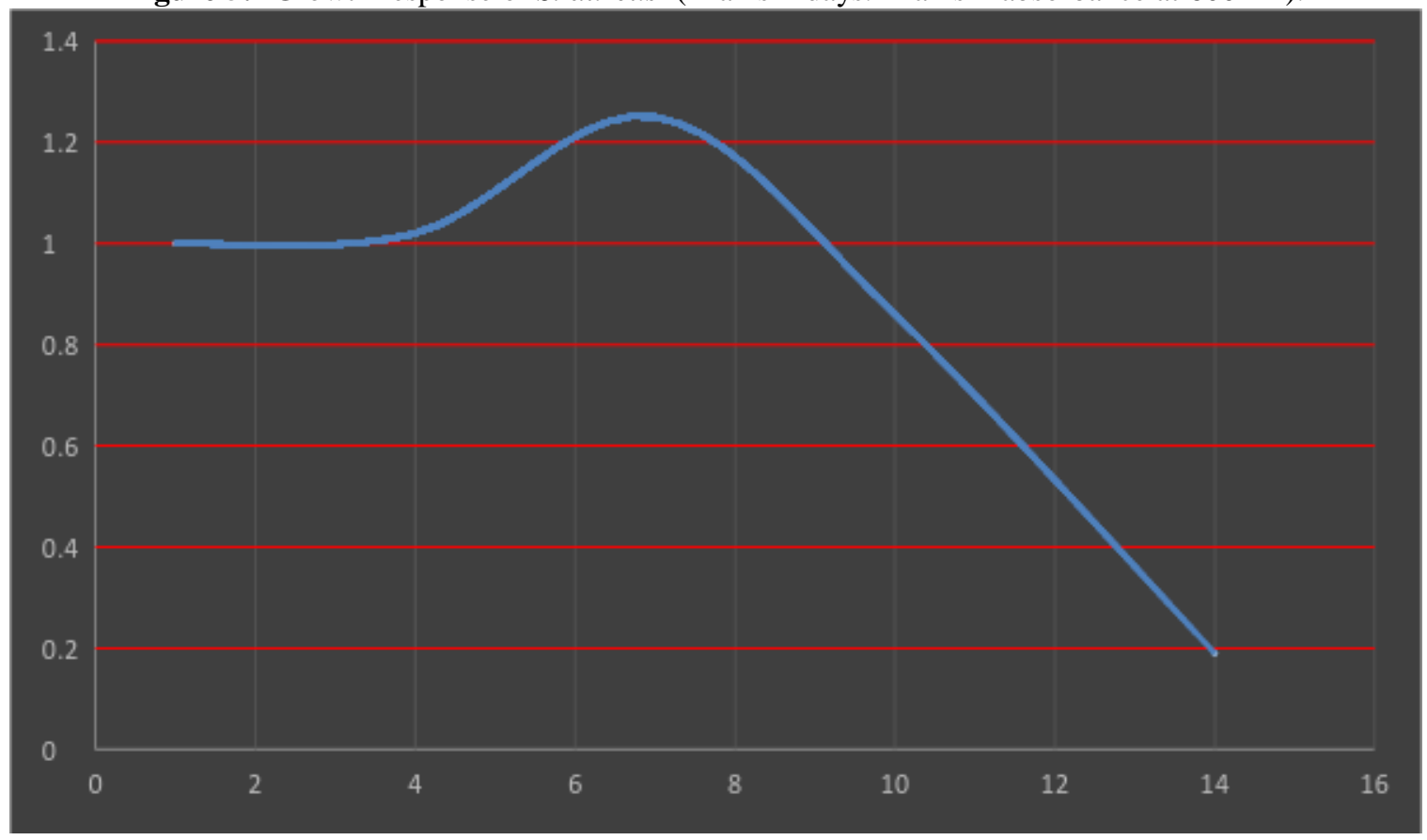


Figure 6:- Degradation of chlorpyrifos by spectrophotometric analysis.

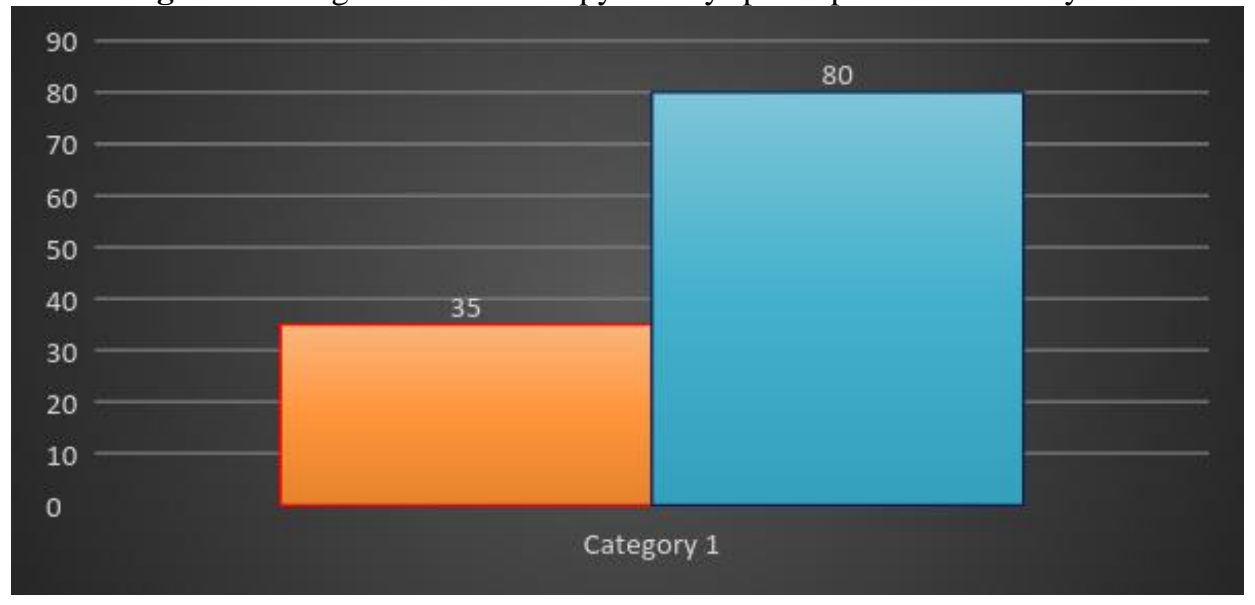

Figure 7:- GC scan showing the peaks for degrading chlorpyrifos by Staphylococcus aureus.

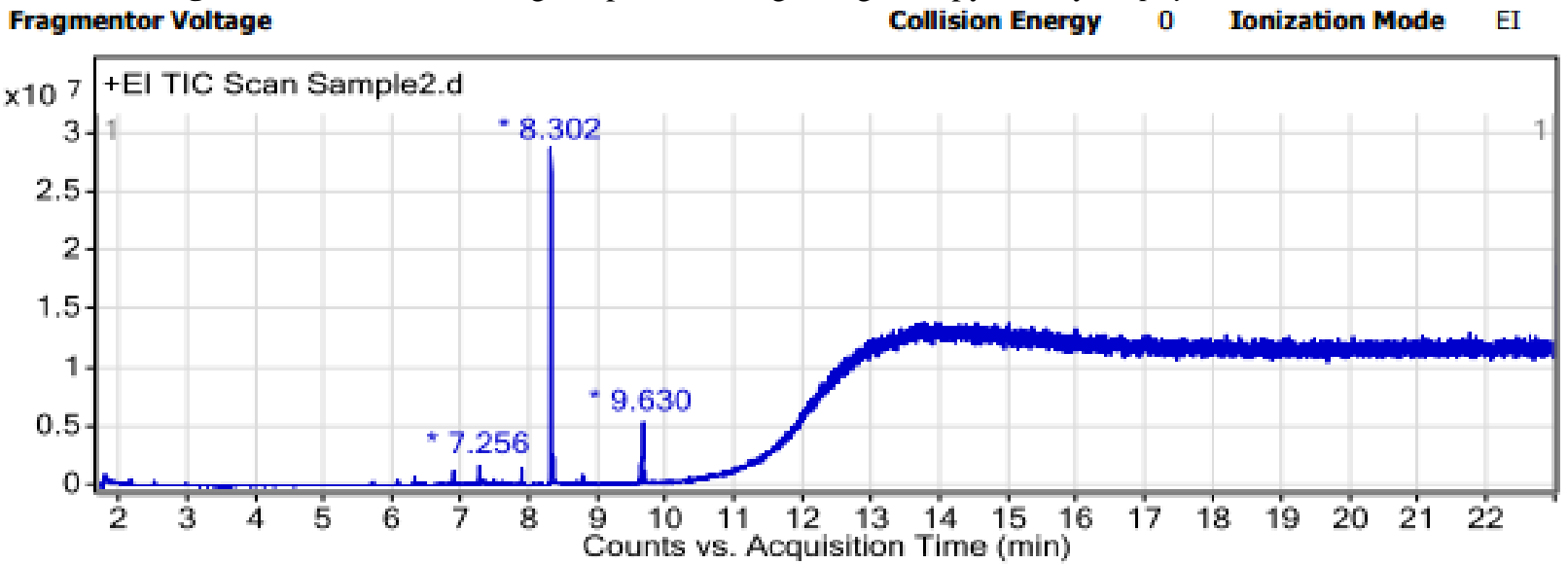

Figure 8:- Peaks of degraded compounds.

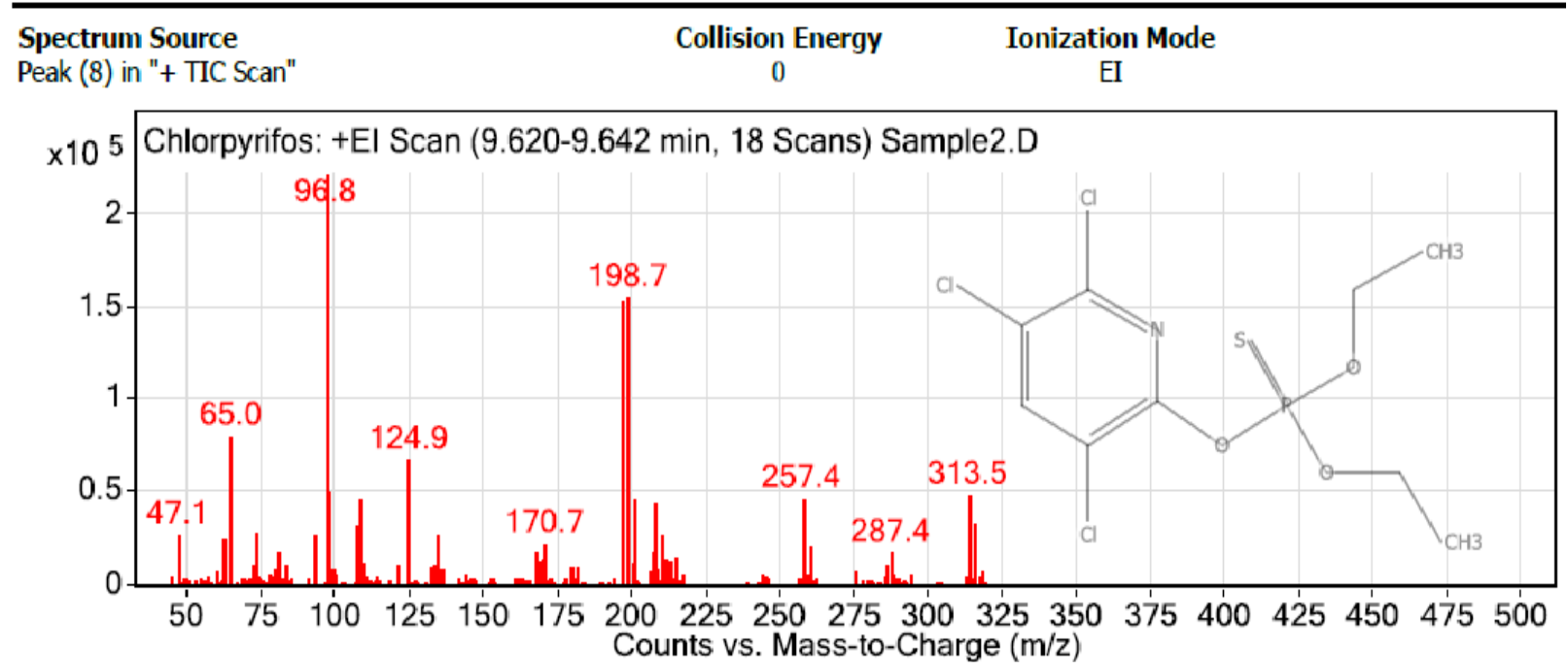


Table 5:- GC scan showing the results for area percentage for each peak

Qualitative Analysis Report

\begin{tabular}{|c|c|c|c|c|c|c|c|}
\hline Peak & Start & RT & End & Height & Area & Area \% & AreaSumPercent \\
\hline 1 & 2.147 & 2.162 & 2.177 & 480474.99 & 338065.53 & 1.59 & 1.08 \\
\hline 2 & 6.275 & 6.31 & 6.331 & 721453.27 & 558329.09 & 2.63 & 1.78 \\
\hline 3 & 6.86 & 6.868 & 6.933 & 1072515.65 & 853714.3 & 4.02 & 2.72 \\
\hline 4 & 7.229 & 7.256 & 7.28 & 1561522.84 & 1423655.21 & 6.7 & 4.54 \\
\hline 5 & 7.849 & 7.874 & 7.9 & 1198120.83 & 840287.66 & 3.96 & 2.68 \\
\hline 6 & 8.278 & 8.302 & 8.318 & 28515911.45 & 21242970.58 & 100 & 67.7 \\
\hline 7 & 8.32 & 8.334 & 8.351 & 2449293.57 & 2311159.77 & 10.88 & 7.37 \\
\hline 8 & 9.618 & 963 & 9642 & 5172075.27 & 3810633.1 & $117 / 94$ & 12.14 \\
\hline
\end{tabular}

Figure 9:- GC scan showing the peaks for degrading chlorpyrifos by Kocuria kristinae.

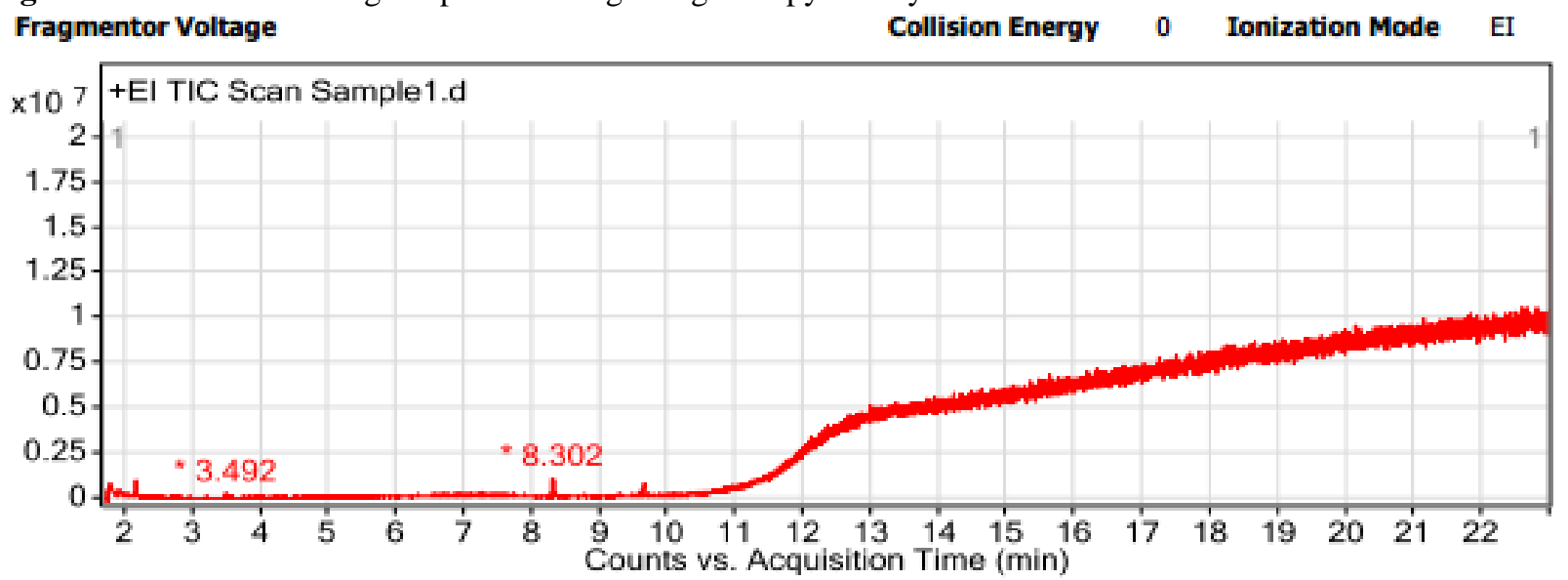

Figure 10:- Peaks of degraded compounds.

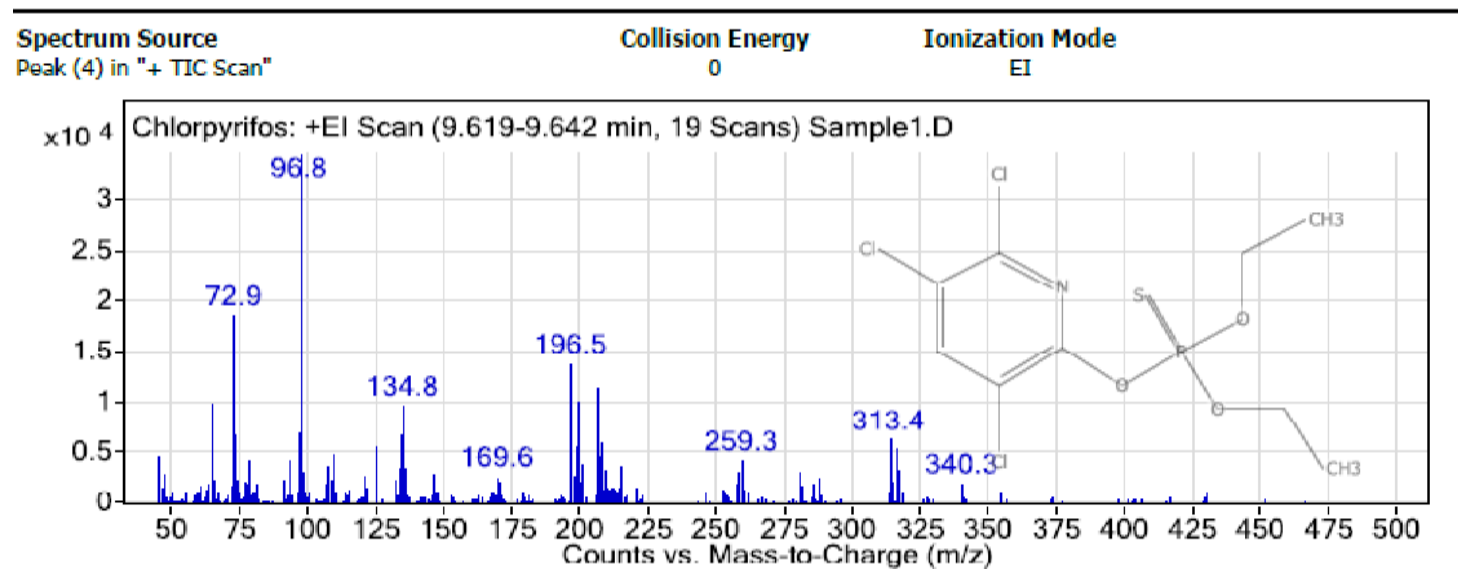


Table 6: GC scan showing the results for area percentage for each peak in Sample -1 (K. kristinae)

\section{Qualitative Analysis Report}

Integration Peak List
\begin{tabular}{|r|r|r|r|r|r|r|r|}
\hline Peak & Start & RT & \multicolumn{1}{l|}{ End } & Height & Area & Area \% & AreaSumPercent \\
\hline 1 & 2.141 & 2.16 & 2.186 & 919084 & 636540.61 & 71.69 & 26.53 \\
\hline 2 & 3.477 & 3.492 & 3.528 & 255566.95 & 260366.89 & 29.32 & 10.85 \\
\hline 3 & 8.275 & 8.302 & 8.315 & 1026427.1 & 887954.84 & 100 & 37.01 \\
\hline 4 & 9.616 & 9632 & 96.652 & 693557.89 & 614686.68 & 69.152 & 25.62 \\
\hline
\end{tabular}

\section{Control:}

Figure 11:- GC scan showing the peaks for chlorpyrifos. Fragmentor Voltage
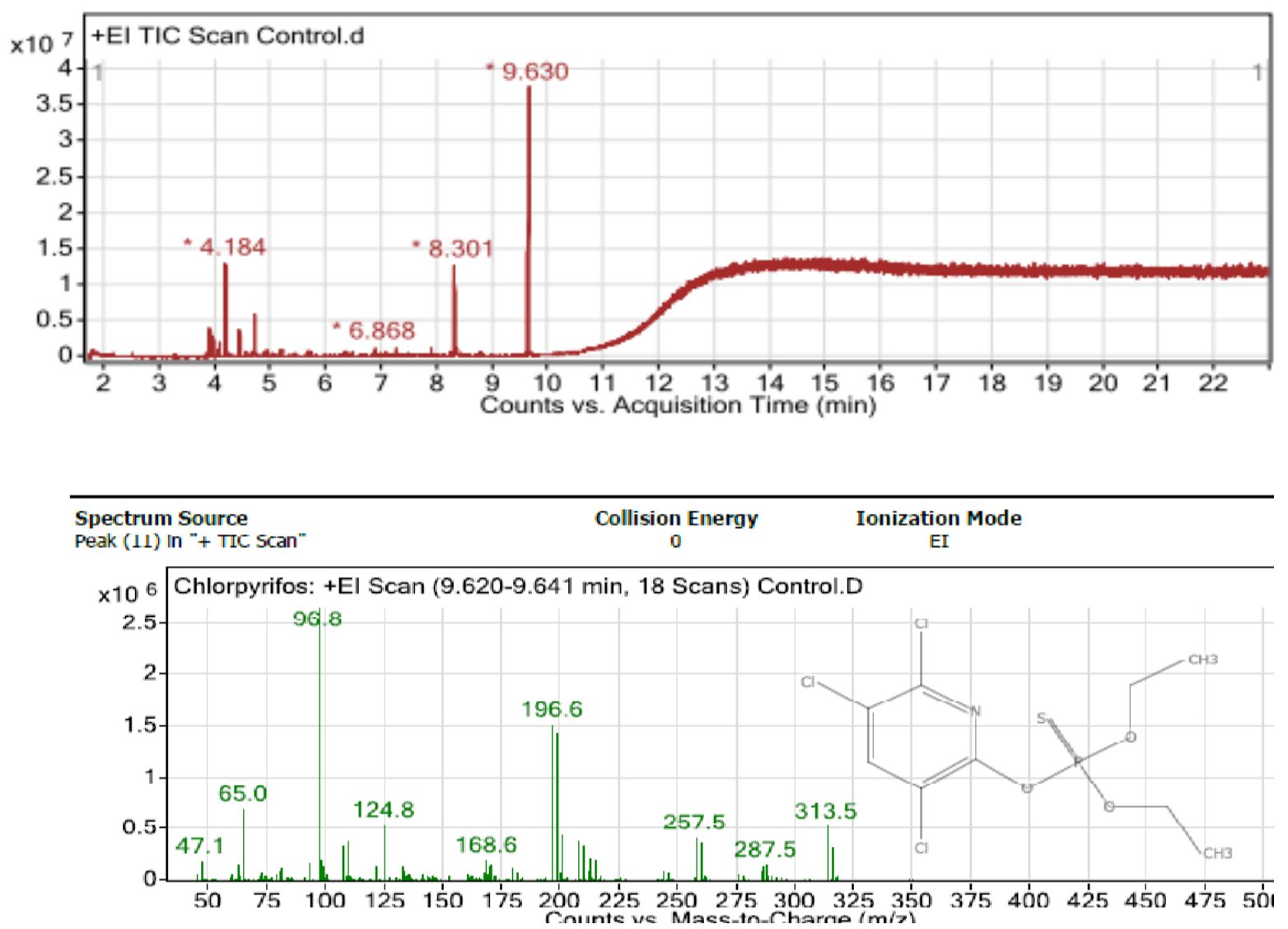
Table 7:- GC scan showing the results for area percentage for each peak

\section{Qualitative Analysis Report}

Integration Peak List
\begin{tabular}{|r|r|r|r|r|r|r|r|}
\hline Peak & Start & RT & \multicolumn{1}{l|}{ End } & Height & Area & Area \% & AreaSumPercent \\
\hline 1 & 3.874 & 3.901 & 3.943 & 3964175.68 & 4714731.06 & 16.36 & 6.87 \\
\hline 2 & 3.953 & 3.964 & 3.981 & 2801125.95 & 2370339.3 & 8.22 & 3.45 \\
\hline 3 & 4.027 & 4.068 & 4.088 & 1955152.06 & 1581598.46 & 5.49 & 2.3 \\
\hline 4 & 4.153 & 4.184 & 4.199 & 12832037.81 & 10592335.47 & 36.75 & 15.43 \\
\hline 5 & 4.399 & 4.435 & 4.459 & 3798412.02 & 3324263.69 & 11.53 & 4.84 \\
\hline 6 & 4.673 & 4.7 & 4.72 & 5802795.04 & 5222630.69 & 18.12 & 7.61 \\
\hline 7 & 6.848 & 6.868 & 6.89 & 1041823.78 & 722147.62 & 2.51 & 1.05 \\
\hline 8 & 7.243 & 7.253 & 7.281 & 974690.71 & 991680.47 & 3.44 & 1.44 \\
\hline 9 & 8.28 & 8.301 & 8.316 & 12525470.2 & 9545538.44 & 33.12 & 13.91 \\
\hline 10 & 9.6 & 9163 & 9.65 & 37254024.23 & 28819076.33 & 100 & 41.98 \\
\hline
\end{tabular}

\section{Reference:-}

1. B. K. Singh and A. Walker. (2006). Microbial degradation of organophosphorus compounds. FEMS Microbiol Rev. 30, 428-471.

2. M. A. Y. Sorgob, E. Vilanova. (2002). Enzymes involved in the detoxification of organophosphorus, carbamate and pyrethroid insecticides through hydrolysis. Toxicol. Lett. 128, 215-228.

3. M. Rani, L. K. Surekha, D. P. Vijaya, M. J. R. Suvarnalatha, J. S. K. Aruna, and G. Narasimha. (2008). Venkateswarlu. Isolation and characterization of a chlorpyrifos degrading bacterium from agricultural soil and its growth response. African J Microbiol Res 2, 026-031.

4. K. J. Parmar, R. S. Tomar, M. V. Parakhia, B. J. Malviya, V. M. Rathod, J. R. Thakkar, V. V. Kothari, A. J. Bhatt, R. L. Bhalara, and B. A. Golakiya. (2014). Isolation and bio-analytical characterization of chlorpyrifos degrading bacteria. J Cell Tissue Res. 14, 4641-4646.

5. Z. Chishti and M. Arshad. (2012). Growth linked biodegradation of chlorpyrifos by Agrobacterium and Enterobacter sp. Int J Agric Biol, 15, 19-26.

6. B. K. Singh, A. Walker, J. A. W. Morgan and D. J. Wright. (2004). Biodegradation of chlorpyrifos by Enterobacter strain B-14 and its use in bioremediation of contaminated soils. Appl Environ Microbiol, 70, 4855-4863.

7. K. Barathidasan, and D. Reetha. (2013). Biodegradation of chlorpyrifos and their intermediate metabolites identified by liquid chromatography mass spectroscopy (LC-MS). Int J Pharm Bio Sci. 4, 1277-1283.

8. M. Ajaz, S. A. Rasool, S. K. Sherwani and T. A. Ali. (2012). High profile chlorpyrifos degrading Pseudomonas putida MAS-1 from indigenous soil: Gas chromatographic analysis and molecular characterization. Int J Basic Med Sci Pharm. 2, 58-61.

9. P. Vijayalakshmi and M. S. Usha. (2012). Isolation, screening and identification of bacteria capable of degrading chlorpyrifos and endosulfan. IJRPS, 2, 68-77.

10. S. R. Naphade, A. A. Durve, M. Bhot, J. Varghese and N. Chandra. (2012). Isolation, characterization and identification of pesticide tolerating bacteria from garden soil. Eur J Exp Biol. 2, 1943-1951.

11. K. B. Rokade and G. V. Malli. (2013). Biodegradation of chlorpyrifos by pseudomonas desmolyticum ncim 2112. Int J Pharm Bio Sci. 4, 609-616.

12. Sharma, A. J. Pandit, R. Sharma and P. Shirkot. (2016). Biodegradation of chlorpyrifos by Pseudomonas resinovarans strain AST2.2 isolated from enriched cultures. Curr World Environ. 11, 267-278.

13. S. Kavi Karunya and D. Reetha. (2012). Biological degradation of chlorpyrifos and monocrotophos by bacterial isolates. Int J Pharm Biolog Arch, 3, 685-691.

14. E. R. El-Helow, M. E. I. Badawy, M. E. M. Mabrouk, E. A. H. Mohamed and Y. M. El-Beshlawy. (2013). biodegradation of chlorpyrifos by a newly isolated Bacillus subtilis strain, Y242. Bioremed J, 17, 113-123.

15. D. S. Bakre, A. A. Sane, G. G. Biradar, and B. B. Kaliwal. (2008). Studies on isolation, characterization and growth of chlorpyrifos degrading bacteria from farm soil. South-Asian Journal of Multidisciplinary Studies. 3, 220-227.

16. F. I. Eissa, H. A. Mahmoud, O. N. Massoud, K. M. Ghanem and I. M. Gomaa. (2014). Biodegradation of chlorpyrifos by microbial strains isolated from agricultural wastewater. J Am Sci, 10.

17. B. Sharma, S. Saxena, A. Datta and S. Arora. (2016). Spectrophotometric analysis of degradation of 
chlorpyrifos pesticide by indigenous microorganisms isolated from affected soil. Int J Curr Microbiol App Sci. $5,742-749$.

18. D.Gulati and M. M. Nisar. Isolation and characterization of chlorpyrifos utilizing bacteria from sugarcane field soil. J Pharm Biomed Sci. 5, 765-770.

19. Sabdono, A. (2006). Biodegradation of chlorpyrifos by a marine bacterium Bacillus firmus Strain BY6 associated with branching coral Acropora sp. J Coastal Dev. 10, 1410-5217.

20. Z. Y. Liu, X. Chen, Y. Shi, and Z. C. Su. (2012). Bacterial degradation of chlorpyrifos by Bacillus cereus. J Adv Mater Res. 356, 676-680.

21. S. Deng, Y. Chen, D. Wang, T. Shi, X. Wu, X. Ma, X. Li , R. Hua, X. Tang, and Q. X. Li. (2015). Rapid biodegradation of organophosphorus pesticides by Stenotrophomonas sp. G1. Journal of Hazardous Materials. 297, 17-24.

22. M. C. Ifediegwu , K. C. Agu, N. S. Awah, A. E. Mbachu, C. B. Okeke, C. G. Anaukwu, P. O. Ubo, U. C. Ngenegbo, and C. M. Nwankwo. (2015). Isolation, growth and indentification of chlorpyrifos degrading bacterial from agriclutural soil in Anambra State, Nigeria. Universal Journal of Microbiology Research. 3, 4652.

23. S. Akbar and S. Sultan. (2016). Soil bacteria showing a potential of chlorpyrifos degradation and plant growth enhancement. Brazilian Journal of Microbiology. 47, 563-570.

24. L. Yang, Y.H. Zhao, B. X. Zhang, C.H. Yang, and X. Zhang. (2005). Isolation and characterization of a chlorpyrifos and 3,5,6- trichloro-2-pyridinol degrading bacterium. FEMS Microbiol Lett. 251, 67-73.

25. H. Jabeen, S. Iqbal1, and S. Anwar. (2015). Biodegradation of chlorpyrifos and 3, 5, 6-trichloro-2-pyridinol by a novel rhizobial strain Mesorhizobium sp. HN3. Water and Environment Journal. 29, 151-160.

26. K. Barathidasan, D. Reetha, D. J. Milton, N. Sriram and M. (2014). Govindammal. Biodegradation of chlorpyrifos by co-culture of Cellulomonas fimi and Phanerochaete chrysosporium. African Journal of Microbiology. 8, 961-966.

27. J. Abraham, A. Shanker and S. Silambarasan. (2013). Role of Gordonia sp. JAAS1 in biodegradation of chlorpyrifos and its hydrolysing metabolite 3,5,6-trichloro-2- pyridinol. Let Appl Microbiol. 57, 510-516.

28. A. A. Romeh and M. Y. Hendawi. (2014). Bioremediation of certain organophosphorus pesticides by two biofertilizers, Paenibacillus (Bacillus) polymyxa (Prazmowski) and Azospirillum lipoferum (Beijerinck). $J$ Agr Sci Tech. 16, 265-276.

29. N. Nagavardhanam and Z. Vishnuvardhan. (2012). Isolation, screening and identification of Organophosphate pesticide degrading Bacterium, Kocuria sp. Asian Journal of Biological and Life Sciences. 1, 204-207.

30. Kumar S. (2011). Bioremediation of chlorpyrifos by bacteria isolated from the cultivated soils. International Journal of Pharma and Bio Sciences. 2, 359-66.

31. J. Cappuccino and N. Sherman. (2010). Microbiology: A Laboratory Manual, 9 edn. San Francisco: BenjaminCummings Publishing Company, Subs of Addison Wesley Longman, Inc.

32. J. G. Holt, N. R. Krieg, P. H. Sneath, J. T. Staley and S. T. Williams. (1994). Bergey's Manual of Determinative Bacteriology.

33. N. Neti and V. Zakkula. (2013). Analysis of chlorpyrifos degradation by Kocuria sp. using GC and FTIR. Current Biotica 6, 466-472.

34. P. Vijayalakshmi and M.S. Usha. (2012). Optimization of chlorpyrifos degradation by Pseudomonas putida. $J$ Chem Pharm Res, 4, 2532-2539.

35. Hindumathy, Gayathri, V. (2013). Effect of pesticide (chlorpyrifos) on soil microbial flora and pesticide degradation by strains isolated from contaminated soil. Bioremediation and Biodegradation, 4, 178-1822. 